\title{
Environmental Education in the Teaching and the Learning of Scientific Disciplines in Moroccan High Schools
}

\author{
Abdelaziz El Moussaouy ${ }^{1,2}$, Jamila Abderbi ${ }^{1} \&$ Mimoune Daoudi $^{3}$ \\ ${ }^{1}$ Centre Régional des Métiers de l'Education et de la Formation, Oujda, Morocco \\ ${ }^{2}$ Laboratoire de Dynamique et d'Optique des Matériaux, Département de Physique, Faculté des Sciences, \\ Université Mohammed I, Oujda, Morocco \\ ${ }^{3}$ Centre d'Etudes et de Recherche Humaines et Sociales, Oujda, Morocco \\ Correspondance: Abdelaziz El Moussaouy, Laboratoire de Dynamique et d'Optique des Matériaux, Département \\ de Physique, Faculté des Sciences, Université Mohammed I, 60000 Oujda, Morocco. Tel: 212-536-500-601/02. \\ E-mail: azize10@yahoo.fr
}

\author{
Received: January 6, 2014 Accepted: February 19, 2014 Online Published: March 24, 2014 \\ doi:10.5539/ies.v7n4p33 \\ URL: http://dx.doi.org/10.5539/ies.v7n4p33
}

\begin{abstract}
In this work we investigate the place and the importance of environmental education (EE) in Moroccan high school education with a focus on Physics/Chemistry and Biology/Geology classes. It is performed within a comparative method by using an interdisciplinary approach in order to understand the presence and the pedagogical styles adopted for the implementation of EE in both disciplines. This study is accomplished via an anthropological theory of knowledge to analyze textbooks and a questionnaire administered to 90 teachers of these disciplines throughout different high schools in Oujda academy, Morocco. The analyses of collected data were performed by adopting a statistical descriptive method. Results show that the presence and the importance of $\mathrm{EE}$ are mediocre and its contribution to learning activity is dominated by informative pedagogical style. Similarly, questionnaire results reveal that the implementation of $\mathrm{EE}$ in their practices cannot enable learners to construct competencies and skills that would help them adopt a positive behavior towards the environment because first, the presence of EE in their classes is almost absent especially in $\mathrm{P} / \mathrm{C}$ classes, second, teachers' practices are overwhelmed by the informative pedagogical style. Furthermore, respondents have never benefited from basic and in-service training and their interdisciplinary professional collaboration is totally lacking.
\end{abstract}

Keywords: environmental education, textbook, teaching, learning, experimental science, high school

\section{Introduction}

Research undertaken by the Arab Forum for Environment (AFED, 2009; Mahmoud, 2009) depicts the risky impacts of global warming on both Arab countries including Morocco. Arab countries may run the risk of high negative effects of climate change due to a shortage in freshwater supply, decreasing food production, diminishing biodiversity and decaying human health (AFED, 2009).

In Morocco, according to a report presented by Laouina (2006) to High Commissariat Plan, which analyzed the actual environmental situation, introduced a prospective of the state of environment in 2030 which depends on the effect of demographic pressure on natural resources, urbanization rhythm and its effects, industrial development, water shortage, liquid and solid waste, and social behavior change.

Recently, a major body of scientists from various disciplines agrees that the environmental dilemma is based on people's behaviors and patterns of thought (Tikka, Kuitunen, \& Tynys, 2000). EE is defined as "a learning process that increases people's knowledge and awareness about the environment and associated challenges, develops the necessary skills and expertise to address the challenges, and fosters attitudes, motivations, and commitments to make informed decisions and take responsible action." (United Nations Educational, Scientific and Cultural Organization [UNESCO], 1978) Many researchers and practitioners think that EE is an outdoor classroom practice such as school environment clubs; however, it increasingly becomes an integral part of school curricula since its benefits have been widely noticed in learner development.

Environmental education mobilizes various participants, including associations, academic institutions, businesses and communities. In Morocco, more and more of these local communities develop environmental 
education actions and projects. Moreover, the global intensity of their commitment is increasing. At the educational level, Morocco has adopted a global pedagogical reform in the beginning of this century via inaugurating a National Charter for Education and Training (1999). This reform puts into focus the integration of EE in educational curricula and programs. In 1999, a study realized by the state secretary charged of water and environment in Morocco and recommended promoting EE in school life (Banque Africaine de Développement [BAD] et Royaume du Maroc, 2007).

There are several ways that EE may have an impact on the learner: cognitive structures may be changed, behaviors and attitudes may be oriented and, the general learning environment may enrich and stimulate further learning and action around environmental issues. In fact, EE develops knowledge, skills and positive attitudes towards the environment and creates responsible citizens who understand the complexity of natural systems and the interrelationships between the components of the environment (Harinder \& Abdul-Rahman, 2012).

Under the pressures of current reforms that focus on standards-based teaching and competency-based education, teachers may lose sight of the value of environmental education. Moreover, science textbooks put enough weight on informative and injunctive styles, which prevents learners to take part in the development and the construction of their knowledge nor do they adopt a positive attitude towards the environment. Although environmental topics may be integrated into various science disciplines, teachers still face the problem of implementing EE in their classroom practices due to inadequate pre-service and in-service training opportunities in this domain which is a hurdle in infusing EE into classroom practices. Besides, contextualized EE problem-solving skills are remarkably absent. Additionally, interdisciplinary education which permits interaction between various science disciplines and teachers' professional collaboration is noticeably weak. Unaware of all the educational opportunities that environmental education presents, teachers believe that the importance of EE is limited to outdoor classroom practices such as school clubs, and related associations.

The purpose of this study is to locate different sites where environmental problems are present and potential ways offered to cope with them in $\mathrm{B} / \mathrm{G}$ textbooks. Secondly, since there is no explicit environmental concept in Physics/Chemistry textbooks, we aim to spot out the density of different Physics concepts that would explicitly help infuse environmental education in the Physics class. Lastly, we aim to measure the importance -if anygiven by teachers and educators to $\mathrm{EE}$ in their classroom practices.

In order to reach these purposes, the research questions raised in this study are the following:

- What is the importance of EE in Moroccan Biology/Geology and Physics/Chemistry education?

- In what ways are the environmental topics covered in the Biology/Geology and Physics/Chemistry textbooks?

- What are the Environmental Education reality and handicaps in Moroccan high school Science practices?

Our starting points in this investigation stem from a number of hypotheses related to our empirical study. First, we believe that the presence of $\mathrm{EE}$ in $\mathrm{B} / \mathrm{G}$ and $\mathrm{P} / \mathrm{C}$ textbooks does not help teachers to actually implement environmental issues in their classroom practices. Second, teachers of Physics are less motivated to integrate EE in their practices than $\mathrm{B} / \mathrm{G}$ teachers. Third, professional interaction and pedagogical collaboration among these teachers about ways of infusing EE is very lacking.

In this paper, we have conducted a theoretical and an empirical study on the place of EE in Moroccan secondary schools namely Biology/Geology and Physics education. To our knowledge, up to now, an interdisciplinary study on EE in secondary school education has not been achieved. We have taken an interdisciplinary approach in order to investigate the implementation of EE in the teaching of $\mathrm{B} / \mathrm{G}$ and Physics. This is performed through a textbook analyses based on knowledge anthropology and a survey based on questionnaires administered to teachers of $\mathrm{B} / \mathrm{G}$ and Physics in different areas in Morocco. We have adopted a comparative approach and a statistical descriptive method in order to analyze data collected. The paper is organized as follows: after introducing the topic, we are going to give a theoretical overview of this study. This is followed by a description of our work methodology. The remaining sections will consider the findings of the textbook analyses and questionnaires. This is followed by an analytical discussion. We end up by a conclusion and perspectives.

\section{Theoretical Framework}

Science education has, for a long time, been taught as a neutral, technical subject largely divorced from its associations with society and its impacts on the environment. In this sense, Brandt (1993), Hewitt (1995) and Fourez (1994) have depicted that science education ran through a crisis. According to these authors, the solution resides principally in curricula interdisciplinary strategies. Curricula interdisciplinary or discipline integration is to constitute a curriculum in a way to articulate learning around objects or phenomena of learning. These strategies allow learners to make connections between their learning and different daily real-life situations 
(Cassie \& Haché, 1998). In this way, in order to sustain the environment, learners have to develop knowledge, skills and positive attitudes on how to interact with the environment in a sustainable manner. Knowledge about the environment and skills on how to live in the environment sustainably can be acquired through education which is referred to as environmental education. EE is a key issue in this interdisciplinary perspective. It is an education that helps learners to aware of their environment and to develop responsible environmental behavior and skills so that they can improve the quality of the environment (UNESCO, 1978; Nordström, 2008).

Objectives, principles, and content of EE have been practically defined in many academic studies and official documents (Bergeson, Fitton, Kennedy, \& Angell, 2000; Palmer, 1997, 1998; Stapp et al., 1969; Sterling \& Cooper, 1992; Volk \& McBeth, 1998). The studies cited above insist on the ability of EE to develop the system of scientific knowledge and positive attitude towards the environment, to construct a comprehension of the necessity of resources preservation, to develop awareness of the problems in this field as well as possible solutions. Knowledge about the environment as such is not enough, it should however enable learners to physically cater for it. To illustrate, learners develop environmental value system such as: responsibility, respect, and environment dangers consciousness (Sauvé, 1995, 2002; Clément \& Hovart, 2000; Clément, 2006).

Education about, in and through the environment are needed according to many scholars specialized in environment issues like Fien (1993), Gough (1992), Tilbury (1995), Palmer (1998) and Palmer and Neal (1994) Giolitto and Clary (1994), Clément and Forissier, (2001); Forissier and Clement (2002, 2003 a, 2003 b); Forissier (2003c) and Clément et al. (2007). In this context, Giolitto and Clary (1994) provide seven conceptions of the environment: environment problem, environment resource, environment nature, global environment, quotidian environment, communitarian environment, and affective environment. We based our theoretical reference on the model (KVP) proposed by Clément $(2006,2007)$. In this model, he suggests the interactions of three poles: scientific knowledge, values, and social practices. Interactions among knowledge (K), values (V), and social practices $(\mathrm{P})$ are important in pedagogical transposition and could be used as a tool in order to identify scientific knowledge and values in a scientific discourse in textbook content.

As to researches in Morocco, Agorram et al. (2010) studied the relationship between Man and the environment in education. They analyzed Biology/Geology high school textbooks during the last twenty five years. Besides, Hamouchi, Essafi, and El Hajjami (2010), have investigated B/G textbooks and have depicted whether Moroccan 2000 educational reform has adopted an environment-based learning content so as to build up EE in national educational system. In addition to these, Khazami, and Ben-Fares, (2009) have conducted an empirical study to measure high and primary school teachers' beliefs concerning environment and environmental education. According to Slali, Hajami, and Essafi, (2010), with respect to competencies approach as a pedagogical innovation adopted by Moroccan educational system, have analyzed three levels of curricula conceptions: national charter, choice of pedagogical orientation, and programs, and have shown the valuable presence of EE recommendations which put weight on developing high school learners' environment competencies. These competencies will allow the learners to react positively and acquire a sense of environment responsibility by adopting an active and participative pedagogical method.

The implementation of EE represents a fundamental challenge to the dominant conception, and knowledge construction, which create for most teachers a conflict with their conception of teaching and learning processes. Therefore, despite the integration of environmental education into Moroccan school curricula, it has not been implemented effectively to improve the state of the environment as expected. The integration of environmental education can be considered a new innovation in education. The introduction and application of new innovations in education require appropriate design and implementation of teacher training programs and in conceptual changes (Rauch \& Steiner, 2005). To increase EE in our schools, teachers must be confident and willing to incorporate EE programs in their classrooms.

To effectively achieve those aims, it is suggested that a constructivist approach could be favorable in EE context. In this sense, EE needs a pedagogical approach which privileges reflection and stimulates problem explorations, EE competence development, which would allow learners to develop a relevant behavior. Such EE related approach should use appropriate pedagogical styles which permit learners to engage in knowledge construction, adopt positive attitudes towards the environment, and participate in the common good of the nation. Caravita et al. (2008) and Abrougui et al. (2007) have determined four pedagogical styles used in textbooks: informative style, injunctive style, persuasive style, and participative style.

\section{Methodology}

\subsection{Textbooks Analysis Methodology}

We have measured the density related to consciousness-raising of environmental problems (EP), the suggested 
solutions and the different terms that designate environmental solutions (ES) in Physics/Chemistry and Biology/Geology textbooks used actually in high schools. We have also analyzed qualitatively the dominant pedagogical style in $\mathrm{B} / \mathrm{G}$ and $\mathrm{P} / \mathrm{C}$ textbooks. The main focus of this quantitative and qualitative analysis is to look for answers to the following questions:

- What are the place and the importance of EE in textbooks?

- What are the dominant pedagogical styles of EE in textbooks?

Table 1. Different analyzed textbooks corresponding to three years in secondary school education

\begin{tabular}{|c|c|c|c|c|c|}
\hline & & \multirow{2}{*}{$\begin{array}{l}\text { Common Trend } \\
\text { (CT) }\end{array}$} & \multirow{2}{*}{$\begin{array}{l}\text { First Year Bac } \\
\qquad(1 \mathrm{Bac})\end{array}$} & \multicolumn{2}{|c|}{ Second Year Bac (2 Bac) } \\
\hline & & & & $\mathrm{B} / \mathrm{G}$ option & $\mathrm{P} / \mathrm{C}$ option \\
\hline \multirow{5}{*}{ 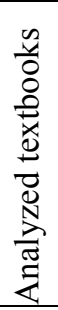 } & $\mathrm{B} / \mathrm{G}$ & Manhal & Al Wadhih & Al Jadid & Fi Rihab \\
\hline & Publishing year & 2005 & 2006 & 2007 & 2007 \\
\hline & $\mathrm{P} / \mathrm{C}$ & Waha & Al Massar & Al Wadhih/ & Al Wadhih/ \\
\hline & & & & Al Massar & Al Massar \\
\hline & Publishing year & 2005 & 2006 & 2007 & 2007 \\
\hline
\end{tabular}

Data for this study were collected from different Physics/Chemistry and Biology/Geology textbooks used in the Moroccan high school educational curriculum. We have chosen the following science students textbooks (Tab. 1).

In this analysis, we have used the notion of density of a chapter in order to give a picture of habitat of EP and ES and the importance given to each in different sites of the textbooks. For a given textbook chapter we define EP and ES positions which appear in each chapter title, each sub-title and each text. For each position we associate a coefficient which indicates its relative importance, respectively 3,2 and 1.

The different functions of presence of terms related to $\operatorname{EP}\left(\delta_{i}\right)\left(E S\left(\delta_{i}\right)\right.$ via position (pi) (i=Title, sub-Title or text) are defined as:

- $\delta_{i}=c_{i}$ if the terms EP or ES appear in pi position which ${ }^{c_{i}}$ are the positions coefficients:

$$
c_{\text {Title }}=3 ; c_{\text {sub-itile }}=2 ; c_{\text {Text }}=1
$$

$-\delta_{i}=0$ if the term is absent.

The position value is defined as the product of the associate number of terms EP or ES occurrence in the positions and the function of its presence.

The density of chapter can be expressed as follows:

$$
\text { Density } D_{E P(E S)}=\frac{\delta_{\text {Title }}+n \delta_{\text {Sub-itite }}+m \delta_{\text {Text }}}{3(p+1)}
$$

Where $\mathrm{n}, \mathrm{m}$ and $\mathrm{p}$ are the Sub-title number which appears the terms EP or ES, the text number which appears a minimum one term of EP or ES and the total sub-title number of considered chapter, respectively.

The density is a number that belongs to $[0,1]$. If $\mathrm{D} \geq 0.5$ then the presence of EP or ES is important in the chapter, if $\mathrm{D}<0.5$ then $\mathrm{EP}$ or ES is a secondary topic in the chapter and if $\mathrm{D}=0$ then EP or ES is absent in the chapter.

Finally, the density shows the importance and the presence of EP or ES in different analyzed textbook chapters. From the density diagram we can get information about the chapters in which EP or ES are important, less important or absent. Generally, by this way of analysis we can have a clear picture about the quantitative importance given to EE by different high school textbooks.

\subsection{Empirical Study Methodology}

The methodological processes adopted in this empirical study are as follows: We have adopted a survey approach whereby we have administered questionnaires to teachers in both disciplines: Physics/Chemistry and Biology/Geology. The questionnaires were delivered in 2012 academic year. We targeted a number of 130 teachers and we got 90 answers (48 answers from P/C teachers, 42 answers from B/G teachers). Our objective 
behind this questionnaire is to know teachers' perception and implementation of $\mathrm{EE}$ in their daily classroom practices. Moreover, we have applied a comparative case study between $\mathrm{P} / \mathrm{C}$ and $\mathrm{B} / \mathrm{G}$ as high school subjects in Moroccan educational system. The comparison is made up of data collected in two different disciplines. The questionnaire consists of 3 parts and 9 questions. Part one revolves around teachers' perception of the environment and $\mathrm{EE}$, and its importance in $\mathrm{B} / \mathrm{G}$ and $\mathrm{P} / \mathrm{C}$ education. Part two addresses the importance of implementing EE in classroom practices. Part 3 focuses on barriers and constraints that hinder the implementation of EE in class practices and the different teachers' suggestions.

\subsection{Data Collection Process and Ethical Consideration}

The process of obtaining participants (teachers) for the research involved two procedures. The first targets teachers of both disciplines $\mathrm{P} / \mathrm{C}$ and $\mathrm{B} / \mathrm{G}$ via visiting them in their schools. The second is via friend email. Most of the teachers were questioned between January 2012 and April 2012, while some were questioned in June 2012.

Before administering the questionnaire, we have explained to teachers our main objectives behind this survey, and we have piloted it among 10 practicing teachers in Oujda and Taourirt delegations in order to measure the feasibility and clarity of the proposed questions. After negotiating the pitfalls, we have added some amendments in order to come to the final version. One of the striking remarks in the piloting stage is that teachers found difficulties in responding to question two, part two that deals with pedagogical styles, which pushed us to mention the four pedagogical styles with their definitions. The language used in delivering questionnaires was Arabic because it is the main language of instruction in high schools and easy to use for teachers.

Our investigation conformed to the ethical guidelines applied in scholarly academic research. In this sense, we have introduced our objectives in this survey in the headings of each questionnaire. Likewise, we have respected the confidentiality of responses through guaranteeing the anonymity of the questionnaires.

\subsection{Analysis Method}

As mentioned above, we have resorted to two methods of data collection: theoretical and empirical. As to data collected from theoretical method, we have based on methodology of work, after regrouping data collection, in order to calculate the different densities corresponding to various secondary levels for both disciplines. In order to give an illustration of data collection, we have converted different data into diagrams using computer software (Excel).

As to data collected from questionnaires, we have divided them into two categories: $\mathrm{P} / \mathrm{C}$ and $\mathrm{B} / \mathrm{G}$ questionnaires. For each question, we tried to determine the frequencies associated with different types of responses. This type of analysis is largely sufficient to reach the results of this survey. We have transformed data collected into percentages and converted them into graphs using computer software (Excel). In addition, for both theoretical and empirical study, the data collection was translated from Arabic into English.

\section{Results and Analysis}

\subsection{Textbooks Analysis}

Our results are presented and discussed in three main parts. The first part is based on a quantitative data analysis which allows us to understand the place and the importance of environment education in the selected textbooks. The second undertakes a qualitative data analysis based on EE pedagogical styles adopted in the aforementioned textbooks. The third part is an empirical study based on a survey conducted on teachers in different high schools in Morocco.

Table 2. Presence of environment issues in $\mathrm{B} / \mathrm{G}$ and $\mathrm{P} / \mathrm{C}$ textbooks corresponding to secondary school education

\begin{tabular}{lccccc}
\hline & & T.C.S & 1.Sc.exp & 2.S.V.T & 2.Sc.Ph \\
\hline \multirow{2}{*}{ Concept of environnement } & S.V.T & ++ & - & - & ++ \\
& S.P.C & $+/-$ & + & + & + \\
\hline
\end{tabular}

In Table 2, we give the degree of the presence of environmental issues in $\mathrm{B} / \mathrm{G}$ and $\mathrm{P} / \mathrm{C}$ textbooks corresponding to high school education (CTs, 1 sc exp., 2sc B/G option, $2 \mathrm{sc}$ P/C option) used according to the recent reform. As shown in this table, in the case of $\mathrm{B} / \mathrm{G}$ textbooks, we notice that environmental issues are present in $\mathrm{CTs}$ and 2 sc option P/C. On the contrary, $1 \mathrm{Sc}$ exp. and $2 \mathrm{~B} / \mathrm{G}$ option, we remark that environmental issues are totally 
absent. However, in $\mathrm{P} / \mathrm{C}$ textbooks, environmental issues are fairly present with the exception of CTs exp. where this presence is relative. Analyzing the results, we note that there is a noticeable gap in 1sc learners' exposure to environmental issues in $\mathrm{B} / \mathrm{G}$ textbooks. This pedagogical discontinuity can have a negative impact on learners and on effective implementation of EE in high school education. Nevertheless, in P/C textbooks, we remark that environmental issues in textbooks are relatively scarce despite the pedagogical continuity noticed in transitions from one level to another. We believe that $\mathrm{P} / \mathrm{C}$ learners lack enough exposure to environmental issues which may affect the development of their environmental competencies.

In order to deeply investigate the presence and importance of EE in textbooks, we have, as depicted above, opted for detecting the habitat and the importance of EP and ES in different textbook chapters. This analysis based on ecology of knowledge (Chevallard, 1999) will allow us to understand where and how much EP and ES are presented in these textbooks.

Table 3. Chapter density of EP present in different chapters in B/G textbooks corresponding to CTs and $2 \mathrm{sc} \mathrm{P/C}$ option and its parameters

\begin{tabular}{lcccccccccc}
\hline & \multicolumn{3}{c}{ T.C.S (Manhal) } & \multicolumn{7}{c}{${ }^{\text {ème }}$ Sc.P.C (Fi Rihab) } \\
\hline Chapters & 2 & 3 & 5 & 10 & 4 & 6 & 7 & 8 & 12 & 13 \\
\hline$\delta_{\text {title }}$ & 0 & 0 & 0 & 0 & 0 & 3 & 3 & 0 & 0 & 0 \\
$\delta_{\text {sub-title }}$ & 2 & 2 & 2 & 2 & 2 & 2 & 2 & 2 & 2 & 2 \\
$\delta_{\text {text }}$ & 1 & 1 & 1 & 1 & 1 & 1 & 1 & 1 & 1 & 1 \\
$\mathrm{n}$ & 1 & 1 & 1 & 1 & 1 & 2 & 4 & 2 & 3 & 2 \\
$\mathrm{~m}$ & 1 & 1 & 2 & 1 & 3 & 2 & 4 & 2 & 4 & 2 \\
$\mathrm{p}$ & 3 & 3 & 2 & 3 & 5 & 3 & 5 & 4 & 12 & 9 \\
\hline $\mathrm{D}$ & 0.25 & 0.25 & 0.44 & 0.25 & 0.28 & 0.75 & 0.83 & 0.4 & 0.26 & 0.2 \\
\hline
\end{tabular}

In Table 3, we depict the calculated density of EP present in different chapters in textbooks corresponding to CT scexp (Manhal) and $2 \mathrm{sc} \mathrm{P/C}$ option (Fi-Rihab) and its parameters. We note that Manhal textbook contains 11 chapters while Fi-Rihab contains 14 ones. As to Manhal textbook, we remark that EP is present in four chapters among 11, while Fi-Rihab textbook, we notice that 6 chapters treat EP among 14 ones, which means that Fi-Rihab sensitizes learners towards the environmental problems around them than Manhal textbook.

We observe that Manhal treats EP $(\mathrm{D}<0.5)$ as a secondary topic in all chapters. On the other hand, two chapters in Fi Rihab treat EP as an important topic. In order to have a good illustration of the density, we have presented in figure 1, the density of chapters for each level (CT sc, $1 \mathrm{sc}$ exp. $2 \mathrm{sc} \mathrm{P} / \mathrm{C}$ option, $2 \mathrm{sc} \mathrm{B} / \mathrm{G}$ option). It is clearly remarked that there is heterogeneity in the distribution of EP density between different levels. The result reveals that only $2 \mathrm{sc}$ P/C option has better exposure to EP than CT sc.

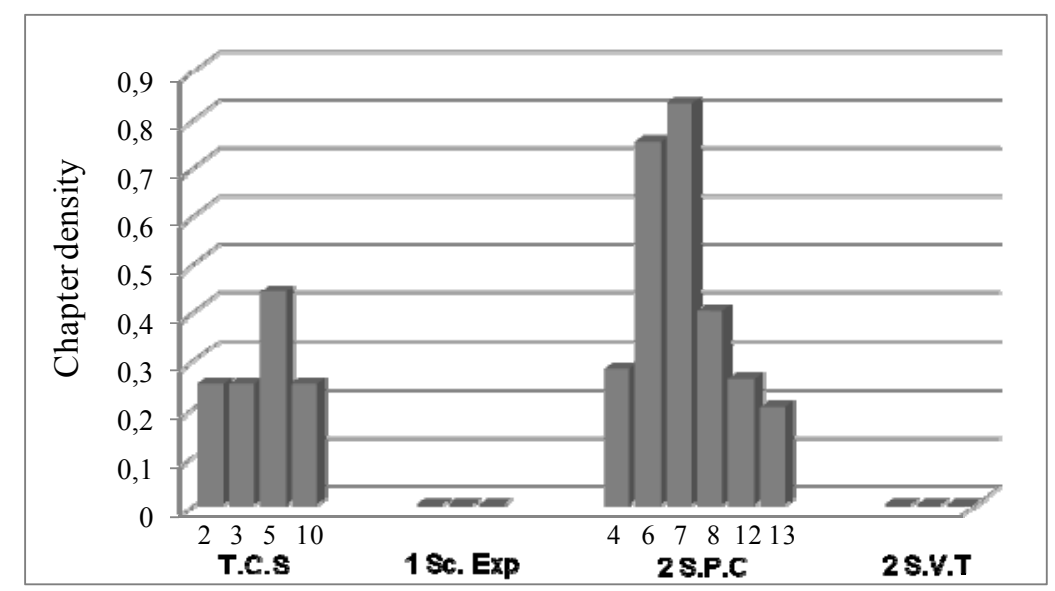

Figure 1. Chapter density of EP in different B/G textbooks for different levels 
As for $\mathrm{P} / \mathrm{C}$ textbooks, similar analysis was adopted. We present in Table 4 . The calculated density of EP present in different chapters in textbooks corresponding to CT sc (Al-Waha), 1 scexp (Al-Massar), 2sc P/C option (Al-Massar/ Al-Wadih) and $2 \mathrm{sc} \mathrm{B/G}$ option (Al-Massar/ Al-Wadih) and its parameters.

Table 4. Chapter density of EP present in different chapters in P/C textbooks corresponding to CTs, 1sc exp, 2sc $\mathrm{P} / \mathrm{C}$ and $2 \mathrm{~B} / \mathrm{G}$ and its parameters

\begin{tabular}{lcccccccccccc}
\hline & $\begin{array}{c}\text { T.C.S } \\
\text { (Al Waha) }\end{array}$ & \multicolumn{3}{c}{$\begin{array}{c}\text { 1èreSc.Exp } \\
\text { (Al Massar) }\end{array}$} & \multicolumn{2}{c}{$\begin{array}{c}\text { 2ème S.P.C } \\
\text { Al Massar/AL } \\
\text { Wadhih) }\end{array}$} & \multicolumn{3}{c}{$\begin{array}{c}\text { 2ème S.V.T } \\
\text { (Al Massar/Al } \\
\text { Wadhih) }\end{array}$} \\
\hline Chapters & 8 & 9 & 21 & 22 & 25 & 33 & 6 & 27 & 28 & 5 & 24 & 25 \\
\hline$\delta_{\text {title }}$ & 0 & 0 & 0 & 0 & 0 & 0 & 0 & 0 & 0 & 0 & 0 & 0 \\
$\delta_{\text {sub-title }}$ & 0 & 0 & 0 & 2 & 0 & 0 & 0 & 0 & 0 & 0 & 0 & 0 \\
$\delta_{\text {text }}$ & 1 & 0 & 1 & 1 & 1 & 1 & 1 & 1 & 0 & 1 & 1 & 1 \\
$\mathrm{n}$ & 0 & 0 & 0 & 1 & 0 & 0 & 0 & 0 & 0 & 0 & 0 & 0 \\
$\mathrm{~m}$ & 2 & 0 & 2 & 1 & 2 & 1 & 1 & 1 & 1 & 1 & 1 & 1 \\
$\mathrm{p}$ & 12 & 13 & 2 & 2 & 3 & 2 & 3 & 2 & 2 & 1 & 2 & 2 \\
\hline $\mathrm{D}$ & 0.05 & 0 & 0.22 & 0.33 & 0.16 & 0.11 & 0.08 & 0.11 & 0.11 & 0.16 & 0.11 & 0.11 \\
\hline
\end{tabular}

The information in Table 4 reveals that EP in common trend is relatively absent since EP is present only in one chapter among 10 chapters while in $1 \mathrm{sc}$ exp. EP is present in four chapters among 33 ones. In $2 \mathrm{sc} \mathrm{P} / \mathrm{C}$ option EP is present in 3 chapters among 30 ones. For 2 sc B/G option 3 chapters present EP among 25 ones. For the sake of illustration, figure 2 represents the chapter density in each textbook for each level. We remark that EP appears in different textbooks but any chapter density exceeds 0.5 , which explains that the importance given to EP in these textbooks is remarkably low. We consider that this situation will not allow learners to benefit from $\mathrm{P} / \mathrm{C}$ education and to make scientific knowledge coupled with environmental literacy.

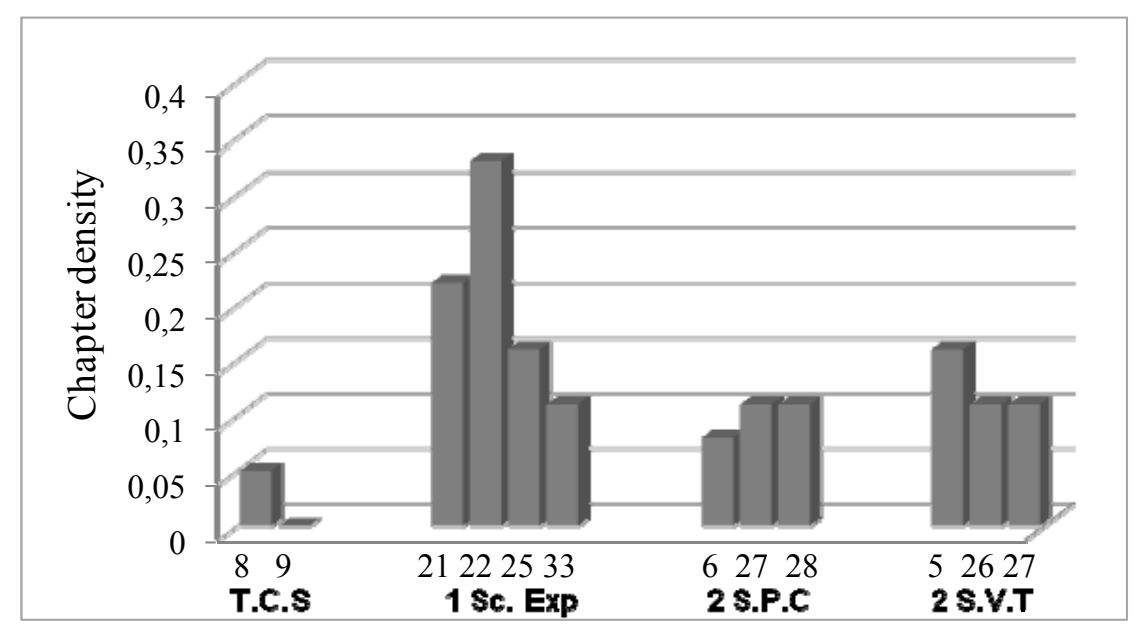

Figure 2. Chapter density of EP in different $\mathrm{P} / \mathrm{C}$ textbooks for different levels

According to the results above, we can highlight that the integration of $\mathrm{EE}$ in terms of $\mathrm{EP}$ in both $\mathrm{B} / \mathrm{G}$ and $\mathrm{P} / \mathrm{C}$ textbooks is not effectively implemented. Additionally, $\mathrm{EP}$ in $\mathrm{P} / \mathrm{C}$ if compared to $\mathrm{B} / \mathrm{G}$ is not given due weight. However, implementing EP in $\mathrm{P} / \mathrm{C}$ education can be achieved through providing contextualized problems. For example, in teaching energy concepts, textbooks can create a context for learners to help them explore environmental problems related to energy.

One of the most effective interests in the area of EE is to provide learners with competencies which enable them 
to engage in looking for solutions to various challenges of EP. So as to reach such an effective learning, we need to introduce learners with cooperative involvement in search for ES. For this reason, we have investigated the sites and the importance of ES in those textbooks.

Table 5. Chapter density of ES present in different chapters in B/G textbooks corresponding to CTs, 2sc P/C and its parameters

\begin{tabular}{lcccccccccc}
\hline & \multicolumn{1}{c}{ T.C.S (Manhal) } & \multicolumn{7}{c}{ 2èmeSc.P.C (Fi Rihab) } \\
\hline Chapters & 2 & 3 & 5 & 10 & 4 & 6 & 7 & 8 & 12 & 13 \\
\hline$\delta_{\text {title }}$ & 0 & 0 & 0 & 0 & 0 & 0 & 0 & 0 & 3 & 0 \\
$\delta_{\text {sub-title }}$ & 0 & 0 & 2 & 0 & 2 & 2 & 2 & 2 & 0 & 2 \\
$\delta_{\text {text }}$ & 1 & 1 & 1 & 1 & 1 & 1 & 1 & 0 & 0 & 1 \\
$\mathrm{n}$ & 0 & 0 & 1 & 0 & 1 & 2 & 1 & 1 & 0 & 1 \\
$\mathrm{~m}$ & 1 & 1 & 1 & 1 & 1 & 3 & 1 & 1 & 0 & 1 \\
$\mathrm{p}$ & 3 & 3 & 2 & 3 & 5 & 3 & 5 & 4 & 12 & 9 \\
\hline $\mathrm{D}$ & 0.08 & 0.08 & 0.33 & 0.08 & 0.17 & 0.58 & 0.33 & 0.13 & 0.08 & 0.1 \\
\hline
\end{tabular}

Table 5 displays the calculated density of ES present in different chapters in textbooks corresponding to CT sc Exp (Manhal) and 2 sc P/C option (Fi-Rihab) and its parameters. In both textbooks, only one chapter gives considerable importance to ES while the other chapters consider it as a secondary topic.

In figure 3, we give the chapter density of various aforementioned textbooks. This is depicted in four levels: CT sc, 1 sc Exp, 2 sc P/C option, and 2sc B/G option. As a result, we have shown that a pedagogical discontinuity between CT sc and $2 \mathrm{sc} \mathrm{P/C}$ option exists. This finding is similar to the ones found above as shown in figure 1 in the case of EP.

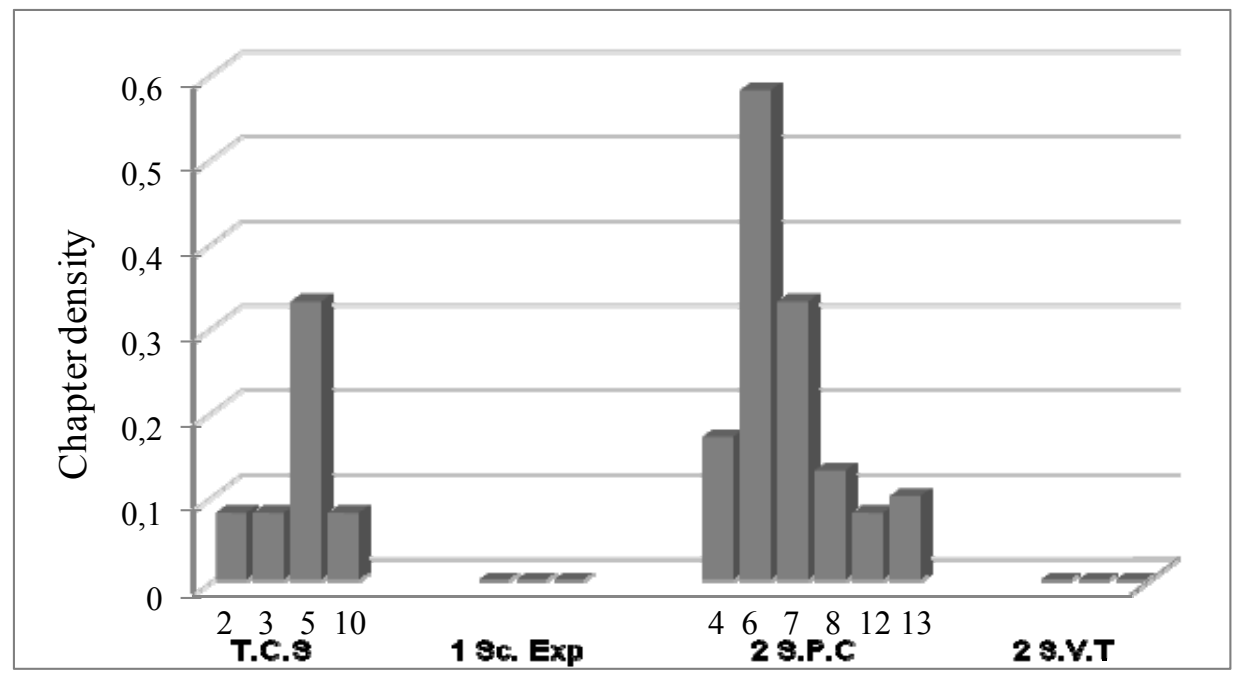

Figure 3. Chapter density of ES in different B/G textbooks for different levels

According to the results (Fig. 1 and 2), we conclude that neither EP nor ES are well-treated in 1 sc Exp textbooks. Learners of $\mathrm{B} / \mathrm{G}$ option are not exposed to EP and ES since their first year in high school. We think that B/G textbooks corresponding to $\mathrm{B} / \mathrm{G}$ option give much importance to discipline knowledge. Furthermore, this result would permit us to conclude that $\mathrm{B} / \mathrm{G}$ textbooks give much importance to insert EE in levels which specialty is different from $\mathrm{B} / \mathrm{G}$. 
Table 6. Chapter density of ES present in different chapters in P/C textbooks corresponding to CTs, 1sc exp, 2sc $\mathrm{P} / \mathrm{C}$ and $2 \mathrm{~B} / \mathrm{G}$ and its parameters

\begin{tabular}{|c|c|c|c|c|c|c|c|c|c|c|c|c|}
\hline \multirow[b]{2}{*}{ Chapters } & \multicolumn{2}{|c|}{$\begin{array}{c}\text { T.C.S } \\
\text { (Al Waha) }\end{array}$} & \multicolumn{4}{|c|}{$\begin{array}{l}1^{\text {ere }} \text { Sc.Exp } \\
\text { (Al Massar) }\end{array}$} & \multicolumn{3}{|c|}{$\begin{array}{c}2^{\text {ème }} \text { S.P.C } \\
\text { (Al Massar/AL Wadhih) }\end{array}$} & \multicolumn{3}{|c|}{$\begin{array}{c}2^{\text {ème }} \text { S.V.T } \\
\text { (Al Massar/Al Wadhih) }\end{array}$} \\
\hline & 8 & 9 & 21 & 22 & 25 & 33 & 6 & 27 & 28 & 5 & 24 & 25 \\
\hline$\delta_{\text {title }}$ & 0 & 0 & 0 & 0 & 0 & 0 & 0 & 0 & 0 & 0 & 0 & 0 \\
\hline$\delta_{\text {sub-title }}$ & 0 & 0 & 0 & 2 & 0 & 0 & 0 & 0 & 0 & 0 & 0 & 0 \\
\hline$\delta_{\text {text }}$ & 0 & 1 & 0 & 1 & 0 & 0 & 0 & 1 & 0 & 0 & 1 & 0 \\
\hline $\mathrm{n}$ & 0 & 0 & 0 & 1 & 0 & 0 & 0 & 0 & 0 & 0 & 0 & 0 \\
\hline $\mathrm{m}$ & 0 & 1 & 2 & 1 & 0 & 0 & 0 & 1 & 0 & 0 & 1 & 0 \\
\hline $\mathrm{p}$ & 12 & 13 & 2 & 2 & 3 & 2 & 3 & 2 & 2 & 1 & 2 & 2 \\
\hline $\mathrm{D}$ & 0 & 0.02 & 0 & 0.33 & 0 & 0 & 0 & 0.11 & 0 & 0 & 0.11 & 0 \\
\hline
\end{tabular}

It remains to understand what happened in P/C textbooks about ES. Thus, in Table 6 we give the calculated density of ES present in different chapters in textbooks corresponding to CT sc (Al-Waha), 1sc.exp (Al-Massar), 2sc P/C option (Al-Massar/ Al-Wadih) and $2 \mathrm{sc} \mathrm{B/G}$ option (Al-Massar/ Al-Wadih) and its parameters. The first result that can be drawn from this table is that only four chapters of textbooks corresponding to all levels considered here contain ES. Moreover, no ES appears in titles of chapters and it appears only in one sub-title in all chapters. Its presence only in texts makes the density of ES in those chapters very weak. In order to clearly understand the behavior of density, we have transformed those results into figure 4 which represents the chapter density of various textbooks mentioned above. This is depicted in four levels: CTsc, 1 Sc.exp, 2 sc.P/C option and $2 \mathrm{sc} \mathrm{B} / \mathrm{G}$ option. The principal result that can be drawn from the $\mathrm{P} / \mathrm{C}$ textbooks analyses of ES allows us to notice that they do not give much importance to it.



Figure 4. Chapter density of ES in different $\mathrm{P} / \mathrm{C}$ textbooks for different levels

Up to now, we have provided a quantitative analysis of EP and ES in P/C and B/G textbooks for all levels of high school education in Morocco. According to the findings, there are many limitations with regard to EP and ES. We have noted that there is a pedagogical discontinuity in EP and ES for B/G textbooks and their distribution is not homogeneous. In addition to this, the density of EP and ES is rather weak. In P/C textbooks, the lack of the presence of EP and ES and their density in chapters is more apparent.

After having quantitatively analyzed EP and ES in textbooks, our aim in what follows is to understand pedagogical styles used to integrate both EP and ES in those textbooks. In fact, EE is not only interested in the quantitative presence of EP and ES but also needs effective pedagogical approaches which are based on 
appropriate pedagogical styles that seek to involve learners' collaborative participation in knowledge construction. This necessitates overcoming traditional styles which impose on learner's ready-made instructions and demands immediate executions.

Table 7. Different pedagogical styles present in $\mathrm{P} / \mathrm{C}$ and $\mathrm{BG} /$ textbooks corresponding to secondary education levels

\begin{tabular}{lrrrrr}
\hline & \multicolumn{2}{c}{ S.V.T textbook } & \multicolumn{3}{c}{ S.P.C textbook } \\
\hline Pedagogical styles & T.C.S & 2.S.P.C & T.C.S & 1 Sc.Exp & 2 S.P.C/S.V.T \\
\hline Informative & +++ & +++ & +++ & +++ & +++ \\
Injunctive & + & + & - & - & - \\
Persuasive & - & - & + & + & + \\
participative & - & $+/-$ & - & - & - \\
\hline
\end{tabular}

In Table 7, we have shown the different pedagogical styles related to EP and ES and which are present in B/G and $\mathrm{P} / \mathrm{C}$ textbooks for different considered levels. Thus, it is clear that informative style is dominant in both textbooks. As to injunctive style, we find it less apparent in these textbooks if compared to informative style. However, persuasive and participative styles are totally absent. These textbooks favour the informative style over participative one which does not allow learners to ask questions, discover problems, reflect upon environmental issues, and provide suggestions resulted from his reflection. In this sense, we can note that despite the fact that the recent reform focuses on EE based on competency approach, its implementation in textbooks remains still ineffective. Preserving the environment requires environment-related competencies and this is not only based on knowledge acquisition, but on learners' responsibility development and positive behaviour towards his environment.

In our analyses of these textbooks, we have also remarked that although the informative style is dominating, documents, pictures, and data are not successfully exploited. A case in point, document No 3 on page 136 in Rihab B/G textbook gives a set of data concerning global warming and the learner is asked to transform this schema into a text that depicts mechanisms of global warming constructions on the surface of earth. In response to this question, learners link just sentences that appear in the schema. The document has not been fully exploited since it just introduces the phenomenon and does not improve in learners how to adopt attitudes in order to diminish the effects of this environmental problem. Another example corresponding to injunctive style in $\mathrm{P} / \mathrm{C}$ textbook Al-Wadih, p. 115, a text (The salin electrolyte battery is corrosive, so it is advisable not to open it or throw it, but it must be picked up in special new treatment areas so as to preserve health and environment) imposes on learners to adopt an attitude without comprehending its dangerous effects. Besides, in Physics textbooks there are two chapters which are concerned with radioactivity. They briefly present the influences of radioactivity on human body without considering the dangers on the environment in the case of nuclear leaking. These chapters are not exploited in depicting the problems of nuclear waste and how to dispose of them.

Now that we have depicted and weighed the interest and the importance of EE in textbooks and the dominant pedagogical styles, let us now consider classroom practices reality by a survey that targeted teachers as they are the essential actors who will put the programs into test.

\subsection{Questionnaires Results}

As mentioned above, the aim of this questionnaire is to collect information from teachers. Data picked up involve teachers' perception of the environment and $\mathrm{EE}$, and its importance in $\mathrm{B} / \mathrm{G}$ and $\mathrm{P} / \mathrm{C}$ instruction, they seek the importance of implementing EE in classroom practices, address difficulties and constraints and the different teachers' suggestions.

Before the teachers responded to what they perceive as environmental education, we asked them through question 1 to explain what environment means. Analysis of the collected data reveals that there were two categories of the teachers' perception of the environment. Some teachers described it as a physical setting around Man (65\%) while others viewed it as a setting influenced by different social practices (35\%). It is clear from this result that teachers have a clear idea about what environment means. However, it seems that the majority of their responses did not include the influences of social practices.

After investigating teachers' perceptions of the meaning of environment, Question 2 addressed their perception 
of EE. Hence, we have detected two categories when analyzing the results. Category one views EE as the environmental knowledge that learners should acquire in order to take care of the environment $(95 \%$ of teachers of $\mathrm{P} / \mathrm{C}$ and $73 \%$ of $\mathrm{B} / \mathrm{G}$ teachers). The second category (5\% of $\mathrm{P} / \mathrm{C}$ teachers and $27 \%$ of $\mathrm{B} / \mathrm{G}$ teachers) sees $\mathrm{EE}$ as competencies and skills that would enable learners to adopt different positive behaviors towards the environment. As seen from this result, majority of teachers of both disciplines consider EE as knowledge which learners should learn. Additionally, this view is held by teachers of $\mathrm{P} / \mathrm{C}$ relatively more than teachers of $\mathrm{B} / \mathrm{G}$. We think that this is due to the fact that teachers of $\mathrm{B} / \mathrm{G}$, because of the nature of their discipline, are more close to $\mathrm{EE}$ than teachers of $\mathrm{P} / \mathrm{C}$. This perception can have an impact on their classroom practices.

Table 8. The percentage of the importance of EE for teachers in both disciplines

\begin{tabular}{lcccc}
\hline & Important & Less important & Not interesting & Don't know \\
\hline P/C teachers & $65 \%$ & $27 \%$ & $8 \%$ & 0 \\
B/G teachers & $93 \%$ & $7 \%$ & 0 & 0 \\
\hline
\end{tabular}

In order to know teachers' views of the importance of EE, we have collected data from responses to question three. Table 8 shows the percentage of the different responses of teachers in both disciplines. As it is clearly depicted in Table 8 , the majority of teachers said that $\mathrm{EE}$ is important $(65 \%$ for $\mathrm{P} / \mathrm{C}$ teachers; $93 \%$ of $\mathrm{B} / \mathrm{G}$ teachers) in teaching $\mathrm{P} / \mathrm{C}$ and $\mathrm{B} / \mathrm{G}$ respectively. We remark that $\mathrm{B} / \mathrm{G}$ teachers consider $\mathrm{EE}$ as an important field in their teaching if compared to teachers of $\mathrm{P} / \mathrm{C}$. In this case, we also think that it is the nature of $\mathrm{B} / \mathrm{G}$ as a discipline which carries concepts of the environment than $\mathrm{P} / \mathrm{C}$ does. We also believe that these responses will have an impact on teachers' classroom practices.

Let us now consider the influences of these perceptions on EE's implementation in teachers' classroom practices. All respondents said that they implement EE in their practices.

Table 9. Different frequencies of the teachers' implementation of EE in both disciplines

\begin{tabular}{cccccc}
\hline$\%$ of EE & $0 \%-10 \%$ & $10 \%-20 \%$ & $20 \%-30 \%$ & $30 \%-40 \%$ & $40 \%-50 \%$ \\
\hline $\mathrm{P} / \mathrm{C}$ & 27 & 13 & 5 & 3 & 0 \\
$\mathrm{~B} / \mathrm{G}$ & 3 & 8 & 9 & 19 & 3 \\
\hline
\end{tabular}

Table 9 represents different frequencies of their implementation in both disciplines. The results demonstrate that a considerable number of $\mathrm{P} / \mathrm{C}$ teachers implement $\mathrm{EE}$ in a frequency less than $10 \%$ in their classes (27 respondents) while $\mathrm{B} / \mathrm{G}$ teachers (19 respondents) use it frequently (30\% and $40 \%)$.

We find that there is a gap between $\mathrm{P} / \mathrm{C}$ teachers' perception of the importance of $\mathrm{EE}$ and their implementation in real class practices. In our opinion, this is due to the nature of $\mathrm{P} / \mathrm{C}$ program which does not help them much to translate EE's perceptions into their class practices.

In question 5, we investigated the ways teachers integrate EE in their practices. Hence, we provided four pedagogical styles (informative, injunctive, persuasive and participative) and we find that the percentage of teachers using informative style is the highest one among teachers in both disciplines. The percentage of teachers of $\mathrm{P} / \mathrm{C}$ who use the informative style is higher $(82 \%)$ than the percentage of $\mathrm{B} / \mathrm{G}$ teachers $(64 \%)$. This result will surely hinder EE innovations among learners and becomes an obstacle in constructing positive attitudes towards the environment.

Through question 6 we have targeted teachers who went through a basic and/or in-service training on EE. The result we get is that all respondents did not benefit from any training about how to implement EE in their classes. This makes EE implementation a personal autonomous initiative. In fact, absence of training in this domain will surely affect the quality of $\mathrm{EE}$ in the educational system.

Besides training, professional collaboration seems to have a positive impact on teachers because it improves teacher professional development. So, we have checked if respondents interact professionally in both disciplines. The result we get reveals that respondents do not interact in an interdisciplinary way in EE. We also find that interaction among teachers in both disciplines is scarce ( $6 \%$ for $\mathrm{P} / \mathrm{C}$ teachers, $13 \%$ for $\mathrm{B} / \mathrm{G}$ teachers). 
Questions 8 and 9 respectively focus on barriers and constraints that hinder the implementation of EE in class practices and the different teachers' suggestions. As to barriers, respondents cite the following barriers that we listed according to their frequency: the nature of the program and textbooks do not permit teachers to effectively implement EE in classes, time devoted to EE is not enough, absence of training, and lack of teaching materials. On what concerns respondents suggestions, we have picked up the following ones: Educators should think of program reform, teachers should be provided by a bank of EE problem-solving activities, teachers suggest to integrate $\mathrm{EE}$ in both basic and in-service training.

\section{Conclusion}

This paper has investigated theoretically and empirically the place and the importance of environmental education in high schools in Morocco namely Physics/Chemistry and Biology/Geology. This was performed by using a comparative study and an interdisciplinary approach. This work was primarily fulfilled by adopting anthropology of knowledge as a framework in order to analyze textbooks of both disciplines. Secondly, by using a statistical descriptive method, we analyzed data collected from questionnaires administered to teachers. Our major findings reveal that the density of EE in textbooks is weak, which implies that the recent textbooks, especially Physics/Chemistry ones, do not give much importance to EE. Despite the importance of the teaching and learning of environmental education, the approach used to implement environmental education in high school tends to marginalize it, because environmental education content and skills are not stated explicitly in both Physics/Chemistry and Biology/Geology textbooks. Furthermore, the dominant pedagogical style in these textbooks is only the informative one. The role of teachers in this operation is fundamental because they enable learners to construct essential knowledge, to develop EE competencies and skills, and to make them develop positive behavior towards the environment. For this reason and in order to enrich this work, we have been interested in collecting data from teachers through a questionnaire. Our principal findings show that teachers do not have not only a unique perception about EE, but their class practices tend to favor the informative pedagogical style and this is clearly depicted in $\mathrm{P} / \mathrm{C}$ teachers' practices. Teachers have never benefited from pre-service or in-service training in $\mathrm{EE}$ and their professional interaction is rather absent. As a result, teachers invest personal efforts to know what to teach and how to teach.

To ensure that environmental education is taught effectively in high schools, we would suggest that the results of this study need to be reflected upon seriously by environmental education stakeholders, particularly curriculum developers, and teacher educators. We expect that the present study would be useful in understanding different aspects of this issue in Moroccan context and would be helpful for researchers to further contemplate and investigate this topic since it is closely related to sustainable development.

\section{References}

Abrougui, M., Abdelli, S., Berthou, G., Khalil, I., Youssef, R., Alaya, A., . . Khzami, S. (2007). Ecologie et éducation à l'environnement: Les styles pédagogiques dans les manuels scolaires de quatre pays francophones. Actes du Meeting IOSTE, Critical Analysis of School Science Textbooks. IOSTE, Hammamet, Tunisia.

Agorram, B., Khazami, S., Selmaoui, S., Abrougui, M., \& Elaboudi, T. (2010). L'Homme et l'Environnement: Quelles conceptions et quels styles pédagogiques utilisés dans les manuels scientifiques de l'enseignement secondaire marocain? RADISMA, 6. Retrieved from http://www.radisma.info/document.php?id=1012. ISSN 1990-3219

Arab Forum for Environment and Development. (2009). Recommendations of the AFED Conference on Climate Change, 24 November 2009. Retrieved from http://www.afedonline.org/en/inner.aspx?contentID $=437$

Banque Africaine de Développement et Royaume du Maroc. (2007). Projet Education V, Rapport d'achèvement.

Bergeson, T., Fitton, R., Kennedy, D., \& Angell, T. (2000). Environmental Education guidelines for Washington schools. Olympia, WA: OSPI.

Brandt, R. (1993). On teaching for understanding a conversation with Howard Gardiner. Educational Leadership, $50(7), 4-7$.

Caravita, S., Valente, A., Pace, P., Valanides, N., Khalil, I., Berthou, G., . . Clément, P. (2008). Construction and validation of textbook analysis grids for ecology and environmental education. Science Education International, 19(2), 97-116.

Cassie, J. R. B., \& Haché, D. (1998). L'utilisation d'une heuristique curriculaire pour créée un apprentissage adapté à la vie. Revue des sciences de l'éducation, 24(3), 3-28. 
Chevallard, Y. (1999). L'analyse des pratiques enseignantes en théorie anthropologique du didactique. Recherches en Didactique des Mathématiques, 19(2), 221-266.

Clément, P. (2006). Didactic Transposition and KVP Model: Conceptions as Interactions Between Scientific knowledge, Values and Social Practices. ESERA Summer School. IEC. Braga, Portugal: Univ. of Minho, $9-18$.

Clément, P., \& Forissier, T. (2001). L'éducation à l'environnement: Les systèmes de valeurs dans les conceptions sur l'Environnement. L'enseignement des sciences expérimentales. 2èmes Journées CIFFERSE, Dakar: ENS, 343-347.

Clément, P., \& Hovart, S. (2000). Environmental Education: Analysis of the didactic transposition and of the conceptions of teachers. In H. Bayerhuber, \& J. Mayer (Eds.), State of the Art of Empirical Research on Environmental Education, Münster, Waxmann Verlag (pp. 77-90).

Clément, P., Laurent, C., \& Carvalho, G. (2007). Methodology for constructing and validating a questionnaire for an international comparative analysis of teachers' conceptions of biology, health and environment: The European project of research Biohead-Citizen. ESERA. Conference, Malmö (Suède), 21-25 Août 2007.

Fien, J. (1993). Education for the Environment: Critical Curriculum Theorizing and Environmental Education. Geelong, Australia: Deakin University Press.

Forissier, T. (2003c). Les valeurs implicites dans l'Education à l'Environnement: analyse de la formation d'enseignants de SVT et des conceptions de futurs enseignants français, allemands et portugais (Thèse de doctorat, Lyon: Univ. Lyon I).

Forissier, T., \& Clément, P. (2002). Variations culturelles des conceptions d'enseignants du Secondaire sur la Nature et l'Environnement. In A. Giordan, J. L. Martinand, \& D. Raichvarg (Eds.), Actes JIES, Univ. Paris Sud), 24, 287-292.

Forissier, T., \& Clément, P. (2003a). Les conceptions de futurs enseignants de sciences de la vie et de la terre (français, portugais et tunisiens) sur un écosystème : avec ou sans cycles? Actes ARDIST, ENFA Toulouse.

Forissier, T., \& Clément, P. (2003b). Les systèmes de valeurs d'enseignants du Secondaire sur la Nature et l'Environnement. Une analyse comparative en France, en Allemagne et au Portugal. In A. Giordan, J. L. Martinand, \& D. Raichvarg (Eds.), Actes JIES (Univ. Paris Sud), 25, 393-398.

Fourez, G. (1994). Alphabétisation scientifique et technique: Essai sur les finalités de l'enseignement des sciences. Bruxelles: De Boeck Université.

Giolitto, P., \& Clary, M. (1994). Eduquer à l'environnement. Paris: Hachette Education.

Gough, N. (1992). Blueprints for Greening Schools. Melbourne: Gould League.

Hamouchi, A., Essafi, K., \& El Hajjami, A. (2010). Intégration de l'éducation relative à l'environnement dans le système éducatif marocain. RADISMA, 5. Retrieved from http://www.radisma.info/document.php?id=893

Harinder, R. S., \& Abdul-Rahman, S. (2012). An Approach of Environmental Education by Non-Governmental Organizations (NGOs) in Biodiversity Conservation. Procedia-Social Behavioural Sciences, 42, 144-152. http://dx.doi.org/10.1016/j.sbspro.2012.04.175

Hewitt, L. (1995). Giving voice to the practicing professional. Orbit, 26(1), 10-14.

Khazami, S., \& Ben-Fares, S. (2009). L'environnement et l'éducation à l'environnement: Conceptions d'enseignants $\mathrm{du}$ primaire et $\mathrm{du}$ secondaire. RADISMA, 4. Retrieved from http://www.radisma.info/document.php?id=748

Laouina, A. (2006). Gestion durable des ressources naturelles et de la biodiversité au Maroc. Prospective «Maroc 2030». Haut Commissariat au Plan.

Mahmoud, A. (2009). Arab world lacks climate change data, says report. News Report, 9 December 2009. Retrieved from http://www.scidev.net/en/news/arab-world-lacks-climate-change-data-says-report.html

Nordstrom, H. K. (2008). Environmental Education and Multicultural Education-Too Close to Be Separate? International Research in Geographical and Environmental Education, 17(2), 131-144. http://dx.doi.org/10.1080/10382040802148604

Palmer, J. A. (1997). Beyond Science: Global Imperatives for Environmental Education in the 21 st century. In P. J. Thompson (Ed.), Environmental Education for the 21st century: International and interdisciplinary perspectives (pp. 3-11). New York: Peter Lang. 
Palmer, J. A. (1998). Environmental Education in the 21st century. Theory, practice, progress and promise. London: Routledge.

Palmer, J., \& Neal, P. (1994). The Handbook of Environmental Education. London: Routledge.

Rauch, F., \& Steiner, R. (2005). University course: Education for Sustainable Development-Innovation in Teacher Education (BINE): Reasons, concept and First experiences. Conference Paper, International Conference "Committing Universities to Sustainable Development", April 20-23, 2005, Graz.

Sauvé, L. (1995). Pour une éducation relative à l'environnement (2ème édition revue 1998). Québec: éd, Guérin, Paris.

Sauvé, L. (2002). L'éducation relative à l'environnement: Possibilités et contraintes. Connexion, revue d'éducation scientifique, technologique et environnementale de l'UNESCO, 27(1/2), 1-4.

Slali, H., Hajami, A., \& Essafi, E. (2010). L'éducation Relative à l'Environnement (ERE) au Maroc entre l'institutionnalisation et l'opérationnalisation pédagogique: Une analyse critique. RADISMA, 6. Retrieved from http://www.radisma.info/document.php?id=1095

Stapp, W. B., Bennett, D., Bryan, W., Fulton, J., MacGregor, J., \& Nowak, P. (1969). The concept of environmental education. Journal of Environmental Education, 1(1), 30-31.

Sterling, S., \& Cooper, G. (1992). In touch: Environmental education for Europe. Surrey, UK: WWF, Panda House.

Tikka, P. M., Kuitunen, M. T., \& Tynys, S. M. (2000). Effects of educational background on students' attitudes, activity levels, and knowledge concerning the environment. Journal of Environmental Education, 31(3), 12-19. http://dx.doi.org/10.1080/00958960009598640

Tilbury, D. (1995). Environmental Education for Sustainability: Defining the new focus of environmental education in the 1990s. Environmental Education Research, 1(2), 195-212. http://dx.doi.org/10.1080/1350462950010206

UNESCO. (1978). The Tbilisi Declaration. UNESCO-UNEP. Environmental Education Newsletter. Connect, $111(1), 1-8$.

Volk, T. L., \& McBeth, B. (1998). Environmental literacy in the United States: A white paper. In H. R. Hungerford, W. J. Bluhm, T. L. Volk, \& J. M. Ramsey (Eds.), Essential Readings in Environmental Education (pp. 75-88).

\section{Copyrights}

Copyright for this article is retained by the author(s), with first publication rights granted to the journal.

This is an open-access article distributed under the terms and conditions of the Creative Commons Attribution license (http://creativecommons.org/licenses/by/3.0/). 